Article

\title{
Formation of Fe- and Mg-Rich Smectite under Hyperalkaline Conditions at Narra in Palawan, the Philippines
}

\author{
Misato Shimbashi ${ }^{1}$, Tsutomu Sato ${ }^{2, *}$, Minoru Yamakawa ${ }^{3}$, Naoki Fujii ${ }^{3}$ and Tsubasa Otake ${ }^{2}$ \\ 1 Graduate School of Engineering, Hokkaido University, N13W8, Kita-ku, Sapporo, Hokkaido 060-8628, Japan; \\ shimbashi.m@gmail.com \\ 2 Division of Sustainable Resource Engineering, Faculty of Engineering, Hokkaido University, N13W8, \\ Kita-ku, Sapporo, Hokkaido 060-8628, Japan; totake@eng.hokudai.ac.jp \\ 3 Radioactive Waste Management Funding and Research Center, Akashi-cho 6-4, Chuo-ku, Tokyo 104-0052, \\ Japan; yamakawa-ytmy@ybb.ne.jp (M.Y.); fujii@rwmc.or.jp (N.F.) \\ * Correspondence: tomsato@hokudai.ac.jp; Tel.: +81-11-706-6305
}

Received: 5 February 2018; Accepted: 8 April 2018; Published: 12 April 2018

\begin{abstract}
The formation of Fe- and Mg-rich smectite and zeolite under alkaline conditions, as secondary minerals after the alkaline alteration of bentonite in repositories for radioactive waste, is of major concern. It is crucial for safety assessments to know whether smectite is formed as a secondary mineral after the alkaline alteration of bentonite. In the present paper, Fe- and Mg-rich smectite, which interacted with the hyperalkaline groundwater at Narra in Palawan, Philippines, was used. Mineralogical and geochemical investigation was conducted to understand the formation process of the smectite and the factors determining the formation of secondary mineral species. The results suggest that a certain amount of smectite may be generated under hyperalkaline conditions, by alteration from amorphous or poorly crystalline components such as M-S-H and F-S-H. Therefore, the controlling factor determining whether smectite or zeolite will be generated as secondary minerals after alkaline alteration of bentonite could be whether nuclei of M-S-H and /or F-S-H are formed. Whether such formation takes place may be determined by the presence of dissolved $\mathrm{Mg}^{2+}$ and $\mathrm{Fe}^{2+}$ in the environment. The formation process of smectite under alkaline conditions, suggested by the results here, is analogous to the generally accepted model of smectite formation as it may have occurred on early Mars.
\end{abstract}

Keywords: Fe- and Mg-rich smectite; alkaline; ophiolite; M-S-H; F-S-H; C-S-H; geological disposal; natural analogue; Mars

\section{Introduction}

Smectite is a commonly occurring clay mineral in a wide variety of surface and near-surface environments on the Earth, which has found use in many industrial applications. For example, in bentonite, which mainly consists of montmorillonite of the smectite group, bentonite is planned for use as a buffer in the geological disposal of radioactive waste due to the favorable properties of smectite, including low permeability and high cation exchange capacity. However, loss of the barrier properties of bentonite has been a concern, where it may react with hyperalkaline leachates from cementitious components in a repository. Much laboratory research has tried to understand the geochemical reactions of bentonite under hyperalkaline conditions to ensure reliable safety assessments. Among previous studies, many have used $\mathrm{NaOH}, \mathrm{Ca}(\mathrm{OH})_{2}$ and / or $\mathrm{KOH}$ solutions as the hyperalkaline leachates and have reported the formation of zeolite [1-3]. However, there is a significant disparity in the time scales and complexity of reactions in laboratory experiments and actual disposal environments. 
Therefore, "natural analogue studies" are necessary to bridge these gaps to understand long-term performance, to assess the quality of actual geological disposals through evaluations, and to ensure public acceptance of such repositories.

A previous natural analogue study examined interactions between bentonite and natural alkaline fluids at the Zambales ophiolite in Luzon, Philippines [4]. There, it was reported that the bentonite alteration zone was limited to less than $5 \mathrm{~mm}$ because of clogging at the interface by secondary formed minerals such as goethite, $\mathrm{K}$-feldspar, and $\mathrm{Fe}$ - and $\mathrm{Mg}$-rich smectite. The limited alteration of bentonite at the interface was attributed to such clogging. Because smectite has the properties of low permeability and high cation exchange capacity, as mentioned above, this suggests that the formation of smectite at interfaces could play an important role as a hydrologic barrier and act to isolate nuclides. Therefore, smectite formation and the subsequent clogging after dissolution of bentonite in a repository would contribute to maintaining the required barrier performance of the bentonite. This geochemical reaction presumably occurs because Fe may be supplied from other engineered barrier components, such as the over-pack and prefabricated engineering barriers, and $\mathrm{Mg}$ could be derived from the bentonite itself, as well as from groundwater. From these considerations, the natural analogue study at the Zambales ophiolite suggests important implications for the understanding of long-term bentonite-hyperalkaline interactions. However, in the environment of that study, the interaction between bentonite and alkaline fluids were complete and the fluid chemistry during the formation of smectite at the site was poorly understood. Therefore, the process of the formation of smectite and the factors determining the formation of secondary mineral species are still uncertain. For this reason, it is not sufficient to draw conclusions of the potential of smectite formation after bentonite dissolution in repositories from the results of the natural analogue study at the Zambales ophiolite.

In the Philippines, there are many hyperalkaline springs from present-day serpentinization of ultramafic rock. The authors identified Fe- and Mg-rich smectite in underground sediments at Narra in Palawan, Philippines, and also hyperalkaline fluids at the same site. Unfortunately, there was no bentonite at this site, and the site was not completely analogous to an engineering barrier system in a repository. However, Fe- and Mg-rich smectite is a concern as a secondary mineral after alkaline alteration of bentonite in repositories, as previously reported [4], and determining which secondary minerals will form after the alkaline alteration of bentonite is important to make an accurate performance assessment of the geological disposal. At this site, the study of the stability of Fe- and $\mathrm{Mg}$-rich smectite or the formation of Fe- and $\mathrm{Mg}$-rich smectite under hyperalkaline conditions was possible. To attempt this, the present study conducted a mineralogical and geochemical investigation to understand the geochemical reaction of smectite under hyperalkaline conditions.

\section{Geological Setting and Samples}

The Philippines Archipelago is surrounded by major continental plates: the Philippines Plate, the Eurasian Plate, the Pacific Plate, the Indo-Australian Plate, and a minor plate called the Sunda Plate. Palawan is an island at the Southeastern margin of the South China Sea on the Sunda plate. The geology of south and central Palawan is dominated by Palawan ophiolite. Palawan ophiolite was detached from the underlying upper mantle following the initiation of subduction at a spreading ridge in the Palaeocene, and thrust onto the Asian margin during the collision, which began in the late Eocene [5]. The emplacement of the ophiolite took place between the Late Oligocene and Early Miocene [6]. The stratigraphic sequence in ophiolite is from tectonized peridotites, cumulate peridotites, layered gabbro, sheeted dike complexes, pillow basalts, and pelagic sedimentary rock. In the ophiolite observed at the ground surface, the peridotites have commonly changed into serpentinite. This occurs at the mantle wedge at depths of 30 to $40 \mathrm{~km}$ below the surface and has been termed "(high temperature) serpentinization".

Samples were collected at Narra, in central Palawan. Figure 1 shows the sampling sites and the studied area in an overhead photo. The main sampling site (Narra3-2) was an alluvial fan channel spreading on a gentle slope of Palawan ophiolite basement. The basement was composed of partially 
serpentinized harzburgite and small amounts of gabbro (Figure 1). Spring water emerged along fractures in the Palawan ophiolite at the top of the fan channel (Narra3-1), and flowed to Narra3-2 on the surface fan deposit as surface water. The surface at Narra3-2 was covered by calcite travertine. Trench and drilling excavations were conducted at Narra3-2. Figure 2 shows an overhead photo of the main sampling site and a cross-sectional view of Narra3-2. Below the travertine deposit, there were deposits of clastic sediments originating from the Palawan ophiolite.

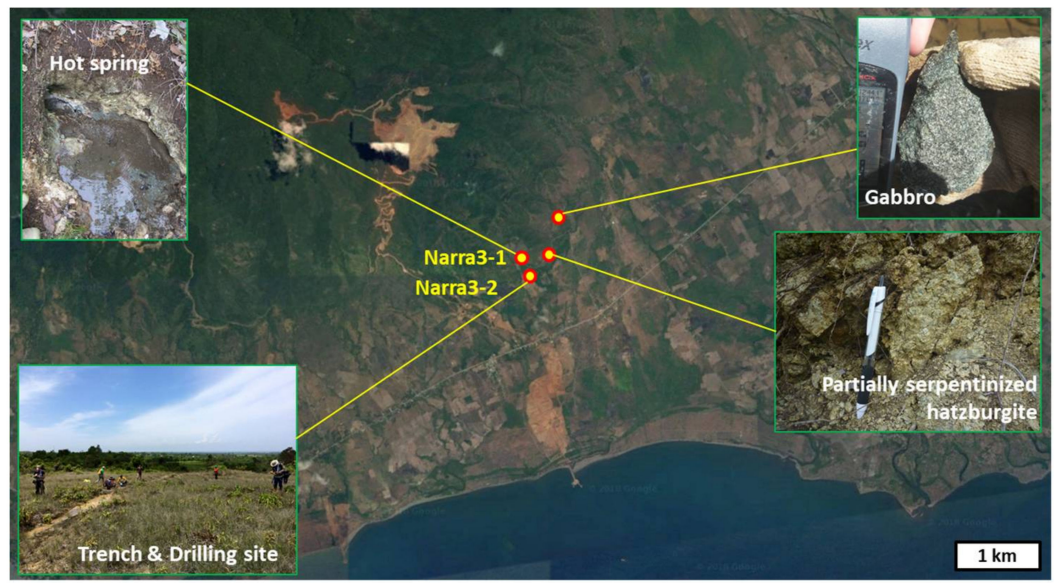

Figure 1. Overhead photo and sampling sites of the studied area.

Locations of trenches and drill holes are shown in Figure 2a. Solid samples were collected from each of the trenches and drill holes. Because the clastic sediments could be collected from a larger area than the basement, 20 samples were collected from different parts of the clastic sediment layer, and these were mainly used for the detailed analysis. Among the samples, core samples from the deepest drill hole (DH4) were analyzed in more detail to understand the long-term interaction between clastic sediments and groundwater. Woods in the clastic sediments at different depths were collected from Trench5 (T5) to estimate the time from the deposition. The location of the core samples from DH4 and woods from T5 are shown in the cross-sectional view of Narra3-2 (Figure 2b).

Water samples were collected from groundwater discharged from the trench walls and drill holes (T1-7 and DH1-4), surface water from different locations at Narra3-2 (up-stream, mid-stream, and down-stream), as well as spring water at Narra3-1.

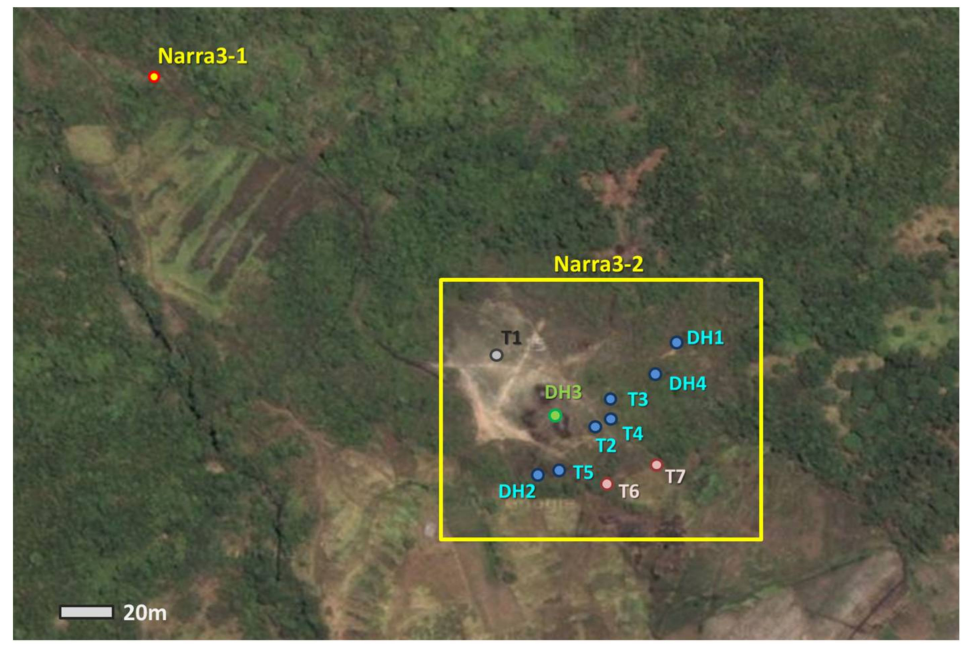

(a)

Figure 2. Cont. 


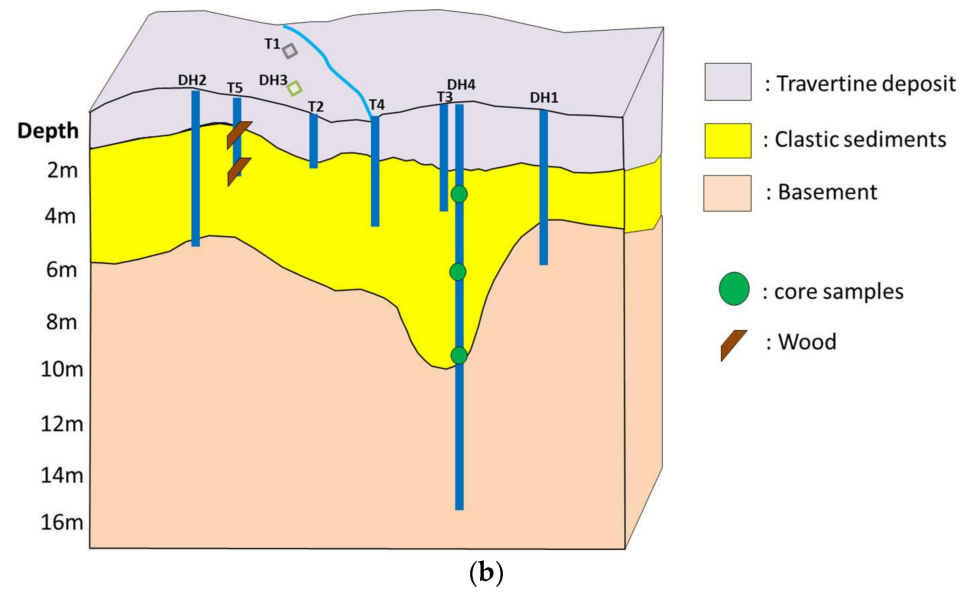

Figure 2. (a) Overhead photo of the main sampling site; (b) Cross-sectional view of Narra3-2.

\section{Methods}

To obtain data on the chemistry of the water samples, the following analyses were conducted. Temperature, $\mathrm{pH}$, and ORP were measured at the sites where the samples were collected. Alkalinity was measured by titrating $\mathrm{HNO}_{3}$ into $50 \mathrm{~mL}$ of water samples that had been filtered through $0.45 \mu \mathrm{m}$ polytetrafluoroethylene (PTFE) membrane filters, also at the site. Additional filtered water samples were obtained by filtering with $0.2 \mu \mathrm{m}$ PTFE membranes, for the determination of cations and anions. Concentrations of major cations were determined by an Atomic Adsorption Spectrometer (AAS) (ZA3300, Hitachi, Co. Ltd., Tokyo, Japan); the concentration of Al was determined by AAS (Z-5010, Hitachi, Co. Ltd.); and the concentration of Si was established by Spectrophotometer (U-1100, Hitachi, Co. Ltd.). Concentrations of the major anions were established by Ion Chromatograph (IC) (ICS-2100, Thermo Scientific, Co. Ltd., Massachusetts, MA, USA).

Clastic sediments and rock samples were air- or freeze-dried, and X-ray diffraction analysis (XRD) was conducted to determine the mineralogical compositions, using an X-ray diffractometer (Multiflex, Rigaku, Co. Ltd., Tokyo, Japan) equipped for graphite-monochromatic $\mathrm{CuK} \alpha$ radiation and operated at $40 \mathrm{kV}$ and $40 \mathrm{~mA}$. Randomly oriented powder samples were scanned from 5 to $70^{\circ} 2 \theta$ at a scanning speed of $0.01^{\circ} \%$ s. The fraction of the samples smaller than $2 \mu \mathrm{m}$ was separated from the coarse fraction by ultrasonic dispersion and centrifugation [7]. Preferred orientation specimens were made by drying the $<2 \mu \mathrm{m}$ diameter fraction suspension and mounting it on glass slides at room temperature with and without ethylene glycol solvation. The ethylene glycol solvation was performed with ethylene glycol vapor at $60{ }^{\circ} \mathrm{C}$ overnight [8]. The samples were analyzed by an X-ray diffractometer (RINT1200, Rigaku, Co. Ltd.) equipped for $\mathrm{CuK} \alpha$ radiation at $30 \mathrm{kV}$ and $20 \mathrm{~mA}$. The samples were scanned from 2 to $40^{\circ} 2 \theta$ at a scanning speed of $0.02^{\circ} / \mathrm{s}$. The randomly oriented powder samples of the $<2 \mu \mathrm{m}$ diameter powder fraction samples were measured to observe the 060 reflection of clay minerals. The 061 reflection is useful to distinguish dioctahedral and trioctahedral clay minerals because d060 is sensitive to the degree of occupancy and the size of cations in octahedral sheets. The samples were scanned from 59 to $63^{\circ} 2 \theta$ using a fixed time scan method with $10 \mathrm{~s}$ for each 0.02 degree.

Selected core samples were embedded in a resin for the thin sections. There were cases of infilled components in the matrix of the clastic sediments and the quantitative analysis of the chemical compositions of these was conducted by an Electron Probe Micro Analyzer (EPMA) (JXA-8530F, JEOL, Co. Ltd., Tokyo, Japan). The structural formula of smectite was determined by the following procedure: (1) assign all $\mathrm{Si}^{4+}$ to the tetrahedral sites; (2) assign all $\mathrm{Al}^{3+}$ to the tetrahedral sites until the tetrahedral site occupancy is 4 , and then assign $\mathrm{Al}^{3+}$ to the octahedral sites; (3) assign all Fe to the tetrahedral sites until the tetrahedral site occupancy is 4 , under the assumption that $\mathrm{Fe}$ is present as $\mathrm{Fe}^{3+}$, and then assign Fe to the octahedral sites; (4) assign all $\mathrm{Mg}^{2+}$ to the octahedral sites; and (5) assign all $\mathrm{Ca}^{2+}, \mathrm{Na}^{+}$ and $\mathrm{K}^{+}$to interlayer sites. 
Minerals in the matrix observed in thin sections were picked out by a micromanipulator (Quick Pro, Micro Support Co. Ltd., Shizuoka, Japan) and hard tool probe (CP-005, Micro Support Co. Ltd.). They were analyzed by a Transmission Electron Microscope (TEM) (JEM-2010, JEOL, Co. Ltd.) to characterize the components in the matrix. An energy Dispersive X-ray Spectroscope (EDS), equipped with the TEM, was also used to confirm that the target particles were those picked out.

Radioactive carbon $\left({ }^{14} \mathrm{C}\right)$ dating of the woods in the clastic sediments was conducted by a tandem-type accelerator mass spectrometer (15SDH-2, National Electrostatics Corporation, Middleton, WI, USA). The ${ }^{14} \mathrm{C}$ decays with time, and the half-life is 5730 years, making ${ }^{14} \mathrm{C}$ dating suitable to estimate times shorter than tens of thousands of years. When wood is growing, the content of carbon isotopes is similar to that of the atmosphere. The ${ }^{14} \mathrm{C}$ content in wood then decays after biological activity stops, and a determination of ${ }^{14} \mathrm{C}$ will show the burial age of the wood. Preprocessing procedures of graphitization of samples was done at the Toki Research Institute of Isotope Geology and Geochronology, Gifu, Japan.

"The Geochemist's Workbench" software package was used for the thermodynamic calculations to obtain phase diagrams for the Mg-Si-Fe-Al-Na system. In the calculations, the thermodynamic database "thermoddem", provided by BRGM, France, was used after the incorporation of equilibrium constants for magnesium silicate hydrate (M-S-H) reported in a previous study [9].

\section{Results}

\subsection{Fluids Analyses}

On-site measurements and concentrations of major cations and anions are reported in Table 1. The results of the chemical analyses showed that both the spring water at Narra3-1 and the groundwater at Narra3-2 were hyperalkaine ( $\mathrm{pH}>11$; Table 1$)$, and had very similar geochemical characteristics in the stiff diagrams (Figure 3), including low dissolved $\mathrm{Mg}^{2+}, \mathrm{Si}^{2+}, \mathrm{Fe}^{(2+3)+}, \mathrm{HCO}_{3}{ }^{-}$ion concentrations, and high dissolved $\mathrm{Ca}^{2+}$ ion concentrations at all sampling depths (1 to $11 \mathrm{~m}$ below the surface) for the groundwater. The chemistry of these samples was similar to that of groundwater from other published ophiolites [10-13].

Table 1. On-site measurements and concentrations of major cations and anions in ppm.

\begin{tabular}{cccccccccccccc}
\hline Sample & $\mathbf{T}\left({ }^{\circ} \mathbf{C}\right)$ & $\mathbf{p H}$ & $\mathbf{O R P}(\mathbf{m V})$ & $\mathbf{N a}^{+}$ & $\mathbf{K}^{+}$ & $\mathbf{M g}^{2+}$ & $\mathbf{F e}^{(2+3)+}$ & $\mathbf{A l}^{3+}$ & $\mathbf{C a}^{2+}$ & $\mathbf{S i}^{2+}$ & $\mathbf{C l}^{-}$ & $\mathbf{S O}_{4}{ }^{2-}$ & $\mathbf{H C O}_{3}$ \\
\hline Narra3-1 & 38.6 & 11.16 & -450 & 48.6 & 2.94 & 0.02 & 0.02 & 0.07 & 37.5 & 0.9 & 29.5 & 0.18 & 0.09 \\
T1 & 30.3 & 11.31 & -176 & 44.6 & 2.12 & 0.02 & 0.02 & 0.01 & 32.2 & 0.7 & 25.6 & 0.08 & 0.77 \\
DH2 & 35.9 & 11.18 & -113 & 40.3 & 2.66 & 0.03 & 0.03 & 0.03 & 24.8 & 5 & 31.3 & 0.10 & 5.6 \\
T5 & 29.9 & 11.36 & -152 & 48.2 & 2.24 & $<0.01$ & 0.01 & 0.13 & 44.8 & 4.1 & 27.8 & $<0.01$ & 3.6 \\
T6 & 27.2 & 10.96 & -107 & 50.1 & 2.46 & 0.01 & 0.02 & 0.19 & 24.6 & 5.77 & 28.5 & 1.92 & 9.2 \\
DH3 & 33.5 & 11.29 & -99 & 51.2 & 2.72 & 0.01 & 0.02 & 0.07 & 33.9 & 2.8 & 28.7 & 0.12 & 1.2 \\
T2 & 28.8 & 11.39 & -160 & 46.1 & 2.32 & 0.02 & 0.02 & 0.08 & 26.9 & 2.5 & 27.3 & 0.13 & 0.67 \\
T7 & 27.7 & 11.16 & -141 & 49.1 & 2.02 & $<0.01$ & 0.02 & 0.18 & 26.8 & 4.27 & 28.6 & 0.63 & 8.9 \\
T4 & 33.4 & 11.17 & -30 & 47.1 & 2.54 & 0.02 & 0.03 & 0.10 & 36.4 & 2.3 & 28.5 & 0.21 & 2.1 \\
T3 & 33.7 & 11.37 & -111 & 50.4 & 2.39 & 0.01 & 0.05 & 0.08 & 48.5 & 2.5 & 27.0 & 0.02 & $<0.01$ \\
DH4 & 33.0 & 11.39 & -119 & 51.8 & 2.96 & 0.02 & 0.03 & 0.06 & 22.4 & 2.9 & 21.1 & 0.14 & 2.8 \\
DH1 & 30.9 & 11.08 & -79 & 51.1 & 3.56 & $<0.01$ & 0.04 & 0.07 & 10.4 & 8 & 31.6 & 0.83 & 2.3 \\
Up-stream & 32.5 & 9.3 & 120 & 52.6 & 2.55 & 18.0 & 0.02 & $<0.01$ & 27.3 & 11 & 36.6 & 0.58 & 275.5 \\
Mid-stream & 33.2 & 9.64 & 120 & 52.4 & 2.55 & 16.0 & 0.02 & $<0.01$ & 22.9 & 10 & 36.2 & 0.53 & 105.9 \\
Down-stream & 32.4 & 9.73 & 115 & 51.7 & 2.42 & 5.00 & 0.02 & $<0.01$ & 9.2 & 4.2 & 35.3 & 0.34 & 100.4 \\
\hline
\end{tabular}

The surface water had different characteristics from those of the hyperalkaline groundwater (Figure 3). The surface water was less alkaline $(\mathrm{pH}<10)$, with higher $\mathrm{Mg}^{2+}$ and $\mathrm{HCO}_{3}{ }^{-}$ion concentrations than in the hyperalkaline groundwater and spring water (Figure 3). The dissolved $\mathrm{Ca}^{2+}$, $\mathrm{Mg}^{2+}$, and $\mathrm{HCO}_{3}{ }^{-}$ion concentrations decreased from up-stream to down-stream (Figure 3). 


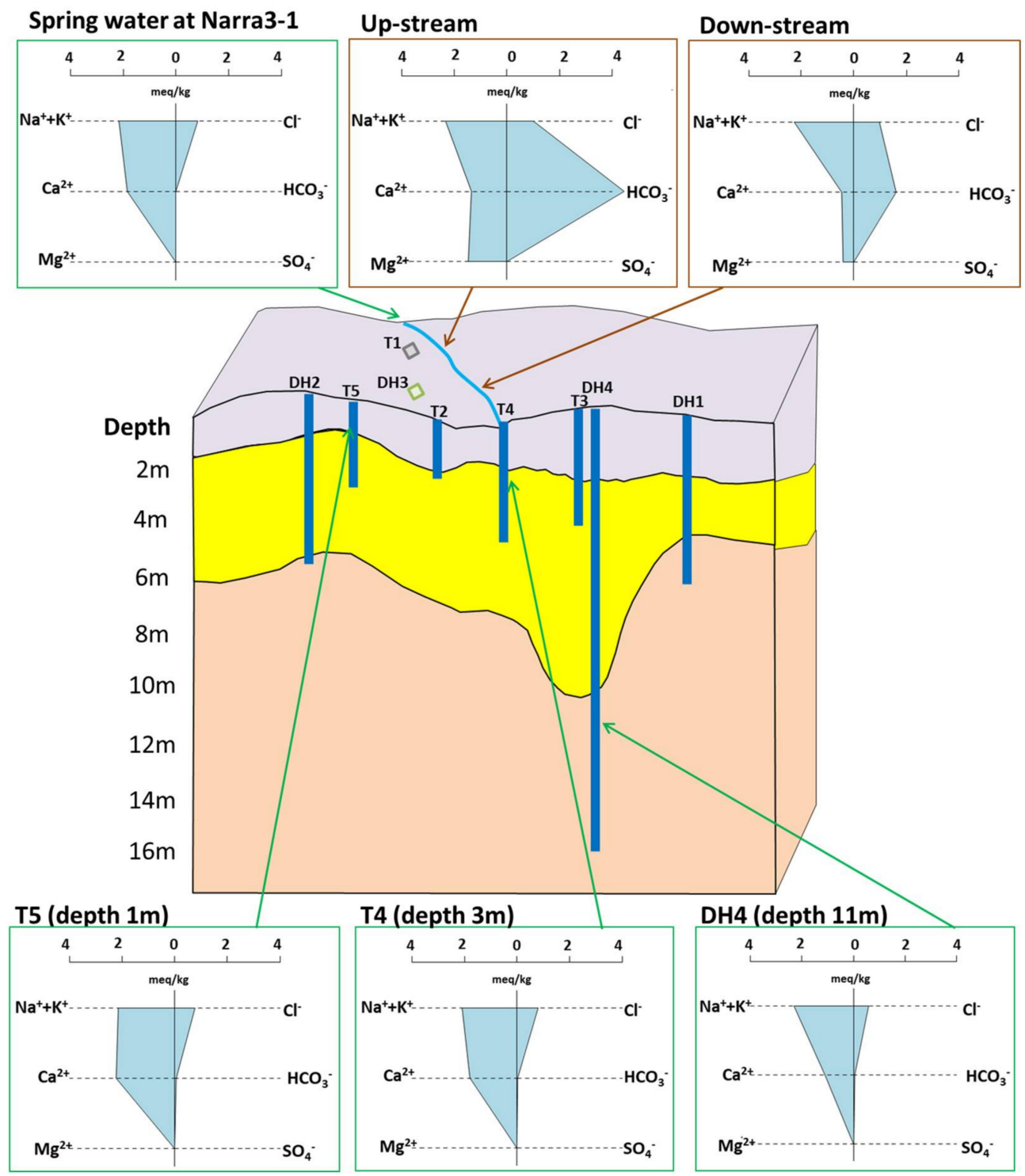

Figure 3. Stiff diagrams of water samples (spring water at Narra3-1, surface water at Narra3-2, and groundwater at Narra3-2, collected from DH2, T5, T4 and DH4).

\subsection{XRD Analyses}

Smectite was identified in all the clastic sediment samples in the XRD measurements of ethylene glycol-solvated and preferred orientation samples. Smectite was found to be present under hyperalkaline conditions, but it was still uncertain whether the smectite at this site was produced by direct precipitation from the hyperalkaline groundwater, by the alkaline alteration of minerals in the clastic sediments, or transported from other locations. Detailed analyses were conducted to understand the formation process of smectite.

Figure 4 shows XRD traces of the samples collected from DH4 (at 3-10 m depth), collected from the clastic sediment layer. Smectite, serpentine, and amphibole were present in all the samples, and tobermorite, pyroxene, talc, and calcite were detected in some samples (Figure 4).

The T1 sample (at the $3 \mathrm{~m}$ depth) was in a more up-stream part of the alluvial fan channel than the other trenches and drill holes (Figure 2). XRD analysis of samples collected at T1 showed only calcite. Compared to the depth of the travertine deposits in the different trenches and drill holes, travertine deposits at T1 were thicker than in the other trenches and drill holes. 


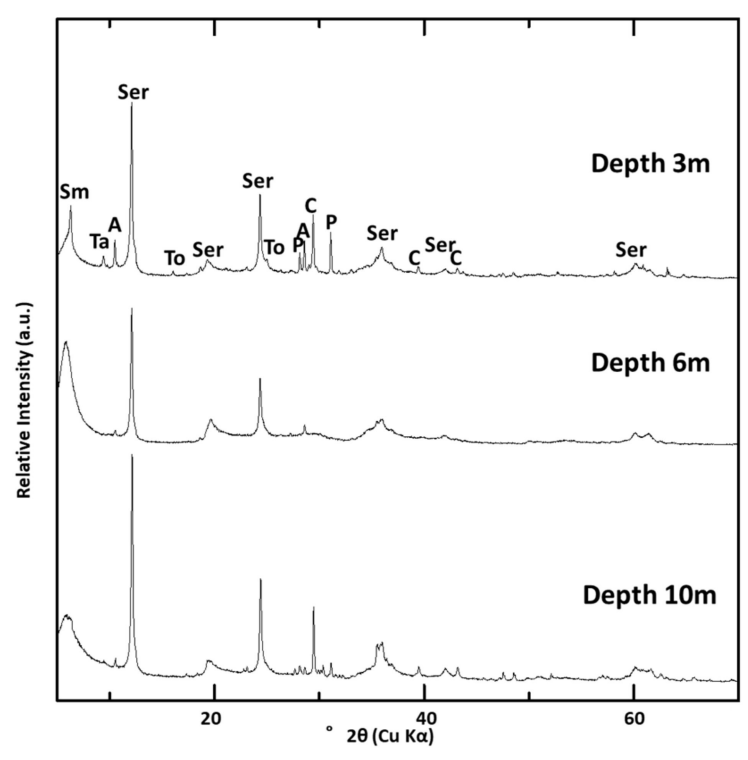

Figure 4. XRD traces of randomly oriented powder samples of DH4 at three depths (3, 6 and $10 \mathrm{~m})$. Sm: smectite; Ser: serpentine; To: tobermorite; Ta: talc; P: pyroxene; A: amphibole; C: calcite.

Figure 5 shows the XRD traces of preferred orientation samples and the 060 reflection of the randomly oriented powder samples in the $<2 \mu \mathrm{m}$ fraction. The intensity of the peaks assigned to smectite was higher in samples from deeper parts of DH4 (6 and $10 \mathrm{~m}$ depth) compared to those from shallower parts of DH4 (3 m depth). This difference was also observed in most of the other samples collected from the clastic sediment layers of the other trenches and drill holes. From the 060 reflection, most of the smectite could be classified as dioctahedral smectite because of the position of the 060 reflection in the smectite-rich samples (Figure $5 \mathrm{e}, \mathrm{f}$ ).

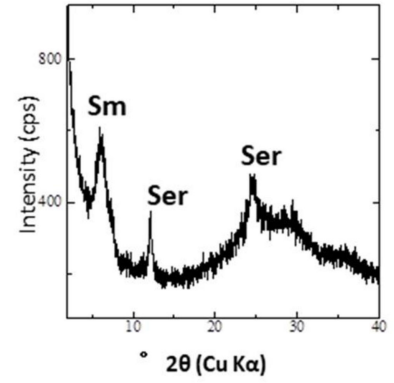

(a)

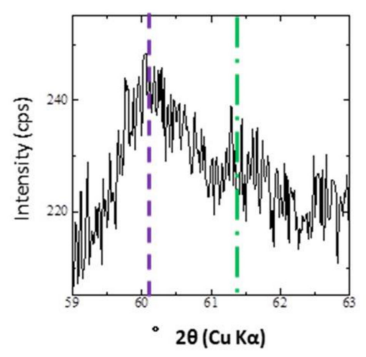

(d)

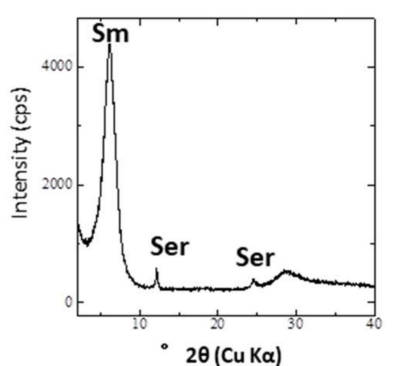

(b)

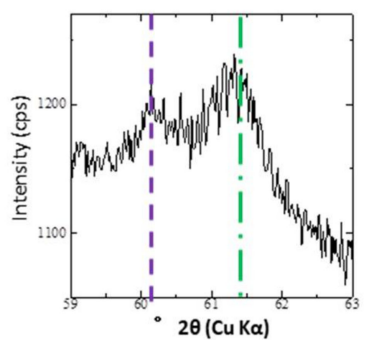

(e)

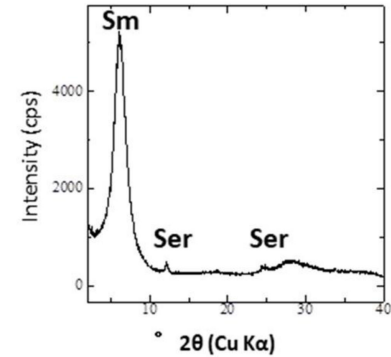

(c)

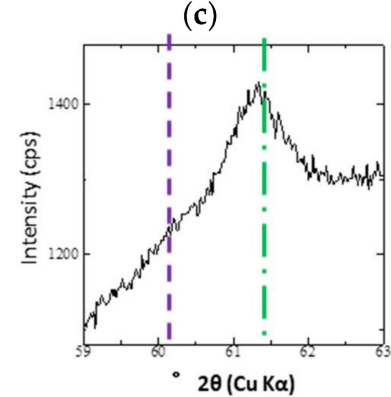

(f)

Figure 5. XRD traces of the $<2 \mu \mathrm{m}$ fraction of DH4 at different depths: (a) Oriented XRD traces at $3 \mathrm{~m}$; (b) Oriented XRD traces at $6 \mathrm{~m}$; (c) Oriented XRD traces at $10 \mathrm{~m}$; (d) XRD traces of the 060 reflection at $3 \mathrm{~m}$; (e) XRD traces of the 060 reflection at $6 \mathrm{~m}$; (f) XRD traces of the 060 reflection at $10 \mathrm{~m}$. Sm: smectite; Ser: serpentine. 


\subsection{EPMA Analyses}

Cases of infilled components in the matrix of the clastic sediments collected from DH4 (at the 3 and $6 \mathrm{~m}$ depths) were observed by EPMA (Figure 6). These samples were chosen for more detailed analysis because the intensity of the peaks assigned to smectite was much smaller than that of the deeper samples, as shown in Figure 5a,b. The minerals in the matrix could be divided into two main categories. One was a solid phase with $\mathrm{Si}, \mathrm{Fe}$, and $\mathrm{Mg}$, and the other was a solid phase with $\mathrm{Si}$ and $\mathrm{Ca}$. The solid phase with $\mathrm{Si}, \mathrm{Fe}$, and $\mathrm{Mg}$ was present as the dominant mineral that filled the matrix of the clastic sediments.

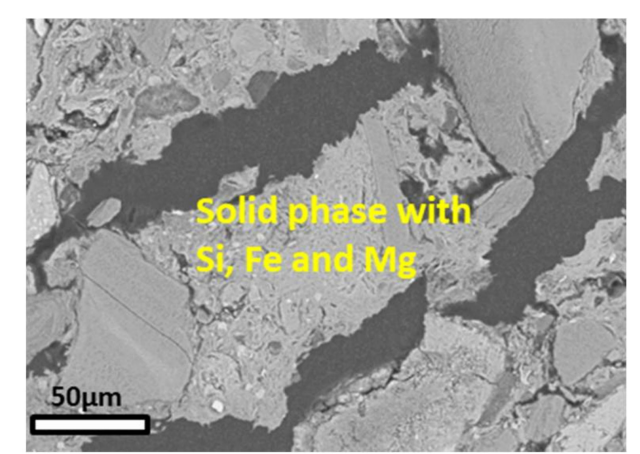

(a)

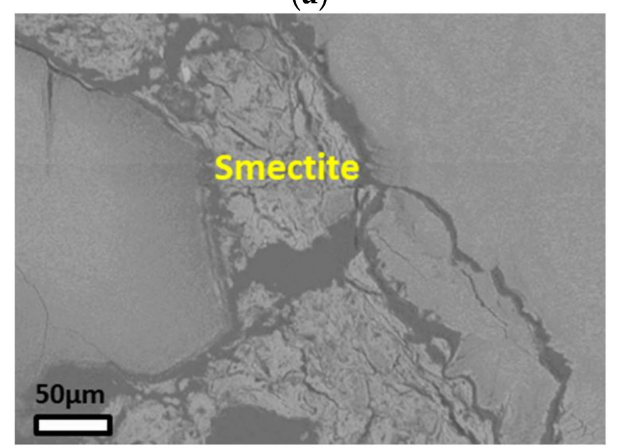

(c)

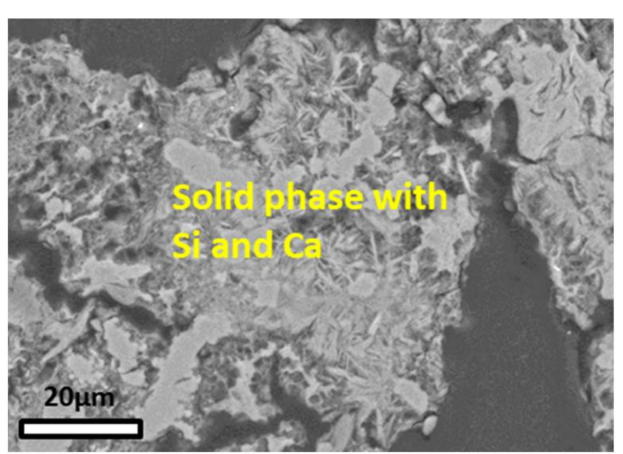

(b)

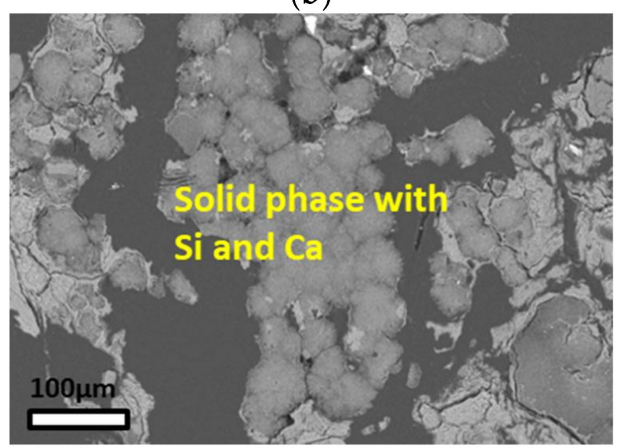

(d)

Figure 6. Minerals in the matrix of the clastic sediments from DH4 at different depths: (a) Solid phase with $\mathrm{Si}, \mathrm{Fe}$, and $\mathrm{Mg}$ at $3 \mathrm{~m}$; (b) Solid phase with $\mathrm{Si}$ and $\mathrm{Ca}$ at $3 \mathrm{~m}$; (c) Smectite at $6 \mathrm{~m}$; (d) Solid phase with $\mathrm{Si}$ and $\mathrm{Ca}$ at $6 \mathrm{~m}$.

The crystal structure of phyllosilicates can be classified into two layer types: 1:1 layer and 2:1 layer. Smectite is a 2:1 layer type, with one octahedral sheet sandwiched between two tetrahedral sheets, and some clay minerals, such as serpentine, are 1:1 layer types with one octahedral sheet bonded to one tetrahedral sheet. Fe- and Mg-rich smectite have $\mathrm{Mg}$ and Fe as the major cations in the octahedral sheets, with small amounts of isomorphous substitution of $\mathrm{Al}$, and it has $\mathrm{Si}$ as the major cation component in the tetrahedral sheets, with small amounts of isomorphous substitution of $\mathrm{Al}_{\text {and }} \mathrm{Fe}^{3+}$. This makes it possible to use the $(\mathrm{Fe}+\mathrm{Mg}) / \mathrm{Si}$ ratio of the solid phase with $\mathrm{Si}, \mathrm{Fe}$, and $\mathrm{Mg}$, to determine the layer types. Table 2 shows the $(\mathrm{Fe}+\mathrm{Mg}) / \mathrm{Si}$ ratios of typical Fe- and $\mathrm{Mg}$-rich smectite, typical serpentine, and the solid phase with $\mathrm{Si}, \mathrm{Fe}$, and $\mathrm{Mg}$, at $3 \mathrm{~m}$ and $6 \mathrm{~m}$. The $(\mathrm{Fe}+\mathrm{Mg}) / \mathrm{Si}$ ratio of typical $\mathrm{Fe}-$ and $\mathrm{Mg}$-rich smectite was about $0.5-0.8$, and the $(\mathrm{Fe}+\mathrm{Mg}) / \mathrm{Si}$ ratio of typical serpentine was about 1.5. From the chemical compositions determined by EPMA, the $(\mathrm{Fe}+\mathrm{Mg}) / \mathrm{Si}$ ratio of the solid phase with $\mathrm{Si}, \mathrm{Fe}$, and $\mathrm{Mg}$, in the matrix at $6 \mathrm{~m}$ was about $0.55-0.88$, and very similar to the ratio of typical Feand Mg-rich smectite (Table 2). This indicates that the solid phase with $\mathrm{Si}, \mathrm{Fe}$, and $\mathrm{Mg}$, in the matrix at the depth of $6 \mathrm{~m}$ shown in Figure 6c was assigned as smectite. The smectite had Fe and Mg with a wide range of $\mathrm{Fe} / \mathrm{Mg}$ ratios from 1.1 to 2.9. The Fe- and $\mathrm{Mg}$-rich smectite contained small amounts of $\mathrm{Al}$, and had $\mathrm{Ca}^{2+}$ as the major interlayer cation. 
Table 2. $(\mathrm{Fe}+\mathrm{Mg}) / \mathrm{Si}$ ratios of typical Fe- and Mg-rich smectite, typical serpentine, smectite from $\mathrm{DH} 4$ at $6 \mathrm{~m}$ and minerals in the matrix of the clastic sediments from DH4 at $3 \mathrm{~m}$. N represents the number of points analyzed.

\begin{tabular}{ccccc}
\hline & Typical Fe- and Mg-Rich Smectite & Typical Serpentine & Ratio at $\mathbf{6 ~ m}$ & Ratio at $\mathbf{3} \mathbf{~ m}$ \\
\hline $\mathbf{( F e}+\mathbf{M g}) / \mathbf{S i}$ & $0.5-0.8$ & 1.5 & $0.55-0.88$ & $1.24-1.51$ \\
$\mathbf{N}$ & - & - & 14 & 16 \\
\hline
\end{tabular}

The solid phase with $\mathrm{Si}, \mathrm{Fe}$, and $\mathrm{Mg}$, in the matrix at $3 \mathrm{~m}$ was not assigned as smectite for the following reasons. The chemical composition of smectite at $6 \mathrm{~m}$ and the minerals that filled the matrix at $3 \mathrm{~m}$ were similar, except for a lower Si content of the minerals that filled the matrix at $3 \mathrm{~m}$. The $(\mathrm{Fe}+\mathrm{Mg}) / \mathrm{Si}$ ratio of the minerals in the matrix at $3 \mathrm{~m}$ was about 1.24-1.51, while at $6 \mathrm{~m}$, which was assigned as smectite, was about $0.55-0.88$. This indicates that the minerals in the matrix at the depth of $3 \mathrm{~m}$, shown in Figure 6a, might not form 2:1 layers, and for this reason they were not assigned as smectite. This phase was characterized as will be shown in Section 4.4 using TEM.

A solid phase with $\mathrm{Si}$ and $\mathrm{Ca}$, was also observed in parts of the matrix of the clastic sediments (Figure $6 \mathrm{~b}, \mathrm{~d}$ ). The components of this mineral were mainly $\mathrm{Si}$ and $\mathrm{Ca}$, and the $\mathrm{Ca} / \mathrm{Si}$ ratio at each of the points were $0.4-0.8$, with a small amount of Fe.

\subsection{TEM Observations}

The solid phase with $\mathrm{Si}, \mathrm{Fe}$, and $\mathrm{Mg}$, that filled the matrix of the clastic sediments from $\mathrm{DH} 4$ at $3 \mathrm{~m}$ was not identified as smectite (see Section 4.3). Samples of this were picked out by micromanipulator for TEM observations, and the results, from the chemical analysis of the constituents using the EDS equipped with the TEM, confirmed that it was these targeted particles that were picked out. Figure 7 shows a TEM image and the corresponding selected-area diffraction (SAD) pattern. The particles here formed an indeterminate aggregate (Figure 7a). The SAD pattern showed three diffuse rings (Figure $7 \mathrm{~b}$ ). The observed d-spacings were $4.55 \AA$, $2.59 \AA$, and $1.53 \AA$. A previous study reported that M-S-H was a low (poorly) crystalline phase with broad humps at about $4.51 \AA, 3.34 \AA, 2.56 \AA$, and $1.54 \AA$ by XRD [9], and the d-spacings, except for that at $3.34 \AA$, were very similar to the observed $\mathrm{d}$-spacings of the particles picked out of the matrix of the clastic sediments from DH4 at $3 \mathrm{~m}$.

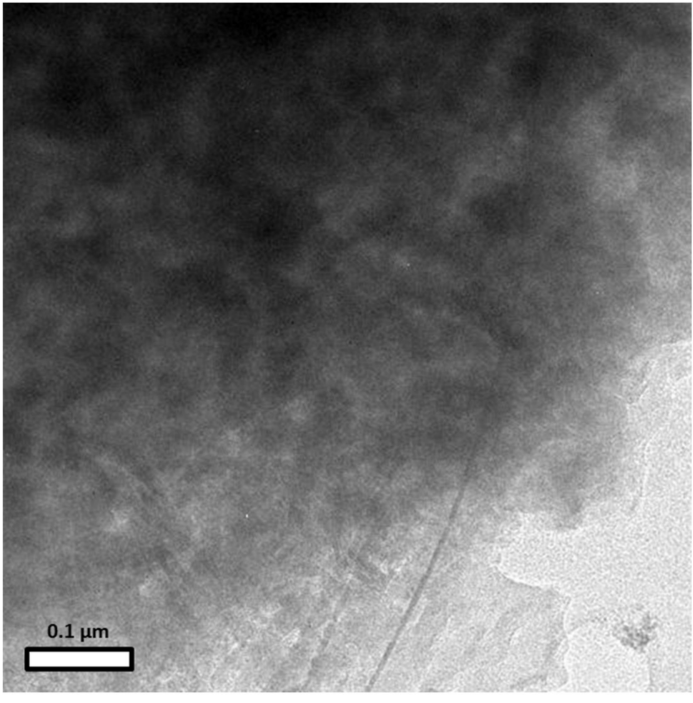

(a)

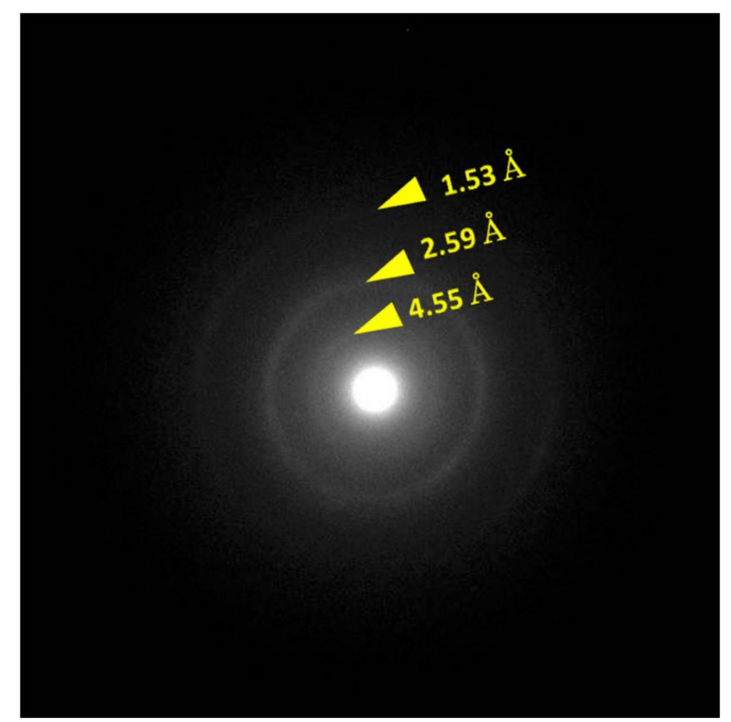

(b)

Figure 7. TEM results for the solid phase with $\mathrm{Si}, \mathrm{Fe}$, and $\mathrm{Mg}$, in the matrix of the clastic sediments from DH4 at 3 m: (a) Low magnification image; (b) SAD pattern of the area in (a). 


\section{5. ${ }^{14} \mathrm{C}$ Dating}

The ${ }^{14} \mathrm{C}$ dating of woods in the clastic sediments collected from $\mathrm{T} 5$ at different depths yielded ages of $2443 \pm 46$ years and $1209 \pm 46$ years. The ${ }^{14} \mathrm{C}$ dating of woods in sediments collected from different depths at $\mathrm{T} 5$ showed the burial age of woods from deeper parts to be older than that of shallower parts.

\section{Discussion}

\subsection{Origin of Hyperalkaline Groundwater and Its Relation to Alkaline Surface Water}

Hyperalkaline groundwater at Narra3-2 and spring water at Narra3-1 had similar chemical characteristics (Figure 3). The chemistry of the samples was similar to that of groundwater from other published ophiolite data [10-13]. These reports have suggested that the geochemical characteristics of fluids are governed by the geochemical reactions of meteoric water with ultramafic rock [12]. This allows us to surmise that the chemistry of both the groundwater and spring water at this site was also likely caused by geochemical reactions of meteoric water with the Palawan ophiolite. The hyperalkaline groundwater at the site was of the $\mathrm{Ca}-\mathrm{OH}$ type. This characteristic is similar to leachates from cement degradation, especially leachates from low alkali cements ( $\mathrm{pH} 9-11)$.

At Narra3-2, the alkaline surface water showed higher $\mathrm{Mg}^{2+}$ and $\mathrm{HCO}_{3}{ }^{-}$ion concentrations than in the hyperalkaline groundwater and spring water (Figure 3), although the field observations suggested that at least some of the surface water would be derived from the spring water at Narra3-1. This could have been due to the mixing of the spring water with other surface water sources that were enriched in $\mathrm{Mg}^{2+}$ and $\mathrm{HCO}_{3}{ }^{-}$ions, and which may have been derived from weathering of the ultramafic rock with meteoric water [12]. The dissolved $\mathrm{Ca}^{2+}, \mathrm{Mg}^{2+}$, and $\mathrm{HCO}_{3}{ }^{-}$ion concentrations decreased from up-stream to down-stream, likely due to the precipitation of carbonate minerals. Carbonate minerals may precipitate when spring water becomes oversaturated with carbonate minerals by mixing with surface water that contains $\mathrm{Mg}^{2+}$ and $\mathrm{HCO}_{3}{ }^{-}$ions at near neutral $\mathrm{pH}$. This is consistent with the observation that travertine deposits were thicker at $\mathrm{T} 1$ and higher in the alluvial fan channel than in other trenches and drill holes. Clastic sediments were covered by travertine deposits. Consequently, the spring water emerging at Narra3-1 had taken part in the formation of travertine deposits at Narra3-2 after the deposition of clastic sediments at the site. Because the surface water at Narra3-2 was a different type than the hyperalkaline groundwater (Figure 3), mixing of the hyperalkaline groundwater at Narra3-2 and surface water in the subsurface environment was not observed.

\subsection{Evidence of the Interaction between Clastic Sediments and Hyperalkaline Groundwater}

Solid phases with $\mathrm{Si}$ and $\mathrm{Ca}$, with $\mathrm{Ca} / \mathrm{Si}$ ratios from 0.4 to 0.8 , were present in the matrix of the clastic sediments from DH4 (at 3 and $6 \mathrm{~m}$ depths) (Figure $6 \mathrm{~b}, \mathrm{~d}$ ). Among the minerals determined in the XRD analysis, a mineral with both $\mathrm{Si}$ and $\mathrm{Ca}$ is tobermorite; therefore, it may be concluded that the solid phases with $\mathrm{Si}$ and $\mathrm{Ca}$ in the matrix of the clastic sediments is tobermorite. In ideal tobermorite, the $\mathrm{Ca} / \mathrm{Si}$ ratio is about 0.8 , and the lower $\mathrm{Ca} / \mathrm{Si}$ ratios than that of tobermorite at some points could be due to the presence of C-S-H or amorphous silica. A previous study has reported the formation of $14 \AA$ tobermorite-like C-S-H at room temperature [14], and C-S-H is well known to form at alkaline $\mathrm{pH}$ in concrete matrixes [15]. This suggests C-S-H formation under alkaline conditions primarily formed as infilling components in the matrix of the clastic sediments and as precursors of the observed tobermorite. The presence of authigenic tobermorite would then indicate that the infilling components in the matrixes of clastic sediments formed by direct precipitation from hyperalkaline groundwater and/or the interaction between the clastic sediments and hyperalkaline groundwater. In situ geochemical reactions involved with hyperalkaline groundwater would also be supported by the evidence of discharge of hyperalkaline groundwater from trench walls and drill holes. 


\subsection{Identification of the Solid Phase with $\mathrm{Si}, \mathrm{Fe}$, and $\mathrm{Mg}$}

From the chemical compositions determined by EPMA, smectite that filled the matrix of the clastic sediments from DH4 at $6 \mathrm{~m}$ was rich in Fe. Because most of the smectite at the site can be classified as dioctahedral smectite based on the 060 reflection in the XRD traces (Figure 5), the Fe in the octahedral sheets of this smectite was mainly ferric. The smectite in the matrix of the clastic sediments from $\mathrm{DH} 4$ at $6 \mathrm{~m}$ also contained $\mathrm{Mg}^{2+}$ in a wide range of $\mathrm{Fe} / \mathrm{Mg}$ ratios, from 1.1 to 2.9, different from what would be expected with ideal dioctahedral smectite at some points. The chemical composition of the smectite from $\mathrm{DH} 4$ at $6 \mathrm{~m}$ was a $\mathrm{Fe}^{3+}$-rich dioctahedral smectite or an intermediate between $\mathrm{Fe}^{3+}$-rich dioctahedral smectite and $\mathrm{Mg}^{2+}$-rich trioctahedral smectite, a type of smectite that has also been reported elsewhere [16,17].

The solid phase with $\mathrm{Si}, \mathrm{Fe}$, and $\mathrm{Mg}$, in the matrix of the clastic sediments from $\mathrm{DH} 4$ at $3 \mathrm{~m}$ was not identified as smectite (Section 4.3) in a location where it was expected that smectite would be observed, in the infillings like in the samples from DH4 at $6 \mathrm{~m}$ (Figure 6c). This is consistent with the results of the XRD analysis of preferred orientation samples, that showed a much lower intensity of the peaks assigned to the smectite in samples from DH4 at $3 \mathrm{~m}$ than of the deeper samples (Figure $5 \mathrm{a}-\mathrm{c}$ ). The major infilled components were separated and appeared in the $<2 \mu \mathrm{m}$ fraction separated by ultrasonic dispersion and centrifugation. Only smectite and serpentine were identified in the XRD traces of the $<2 \mu \mathrm{m}$ fraction (Figure $5 \mathrm{a}$ ). The solid phase with $\mathrm{Si}, \mathrm{Fe}$, and $\mathrm{Mg}$, in the matrix of the clastic sediments from DH4 at $3 \mathrm{~m}$ were not assigned as smectite, based on chemical composition. This made it plausible to assign the solid phase with $\mathrm{Si}, \mathrm{Fe}$, and $\mathrm{Mg}$, in the matrix of the clastic sediments from DH4 at $3 \mathrm{~m}$ as serpentine, as shown in the XRD traces or X-ray amorphous material. The d-spacing obtained from the SAD pattern of particles picked from the matrix of the clastic sediments from DH4 at $3 \mathrm{~m}$ was very similar to the M-S-H reported elsewhere [9]. This M-S-H is considered a precursor to phyllosilicates such as smectite, talc, serpentine and/or sepiolite $[9,18,19]$, although this is not entirely clear and needs further substantiation. A previous study reported on the nuclei of a trioctahedral ferrous stevensite under reducing conditions after aging coprecipitated gel of silica and $\mathrm{Fe}^{2+}$-sulphate at a low temperature $\left(75^{\circ} \mathrm{C}\right)$ [20]. In that laboratory experiment, no crystallization of these nuclei into smectite was observed after exposure to reducing conditions for 15 days, and subsequent oxidation induced a rapid crystallization of ferric nontronite-like smectite after a few weeks. The synthetic smectite had broad peaks with d-spacings at about 14-15.5, $4.54 \AA$, $3.41 \AA, 2.61 \AA, 2.28 \AA, 1.70 \AA$ and $1.52 \AA$ in the XRD traces. The reported peaks at $14-15.5 \AA$ were very low and indistinct. This suggests a crystal structure similar to a precursor of smectite, maybe a poorly crystalline phase with $\mathrm{Fe}$ and $\mathrm{Si}$, such as iron silicate hydrate (F-S-H) rather than smectite. Table 3 shows the d-spacings of the solid phase with $\mathrm{Si}, \mathrm{Fe}$, and $\mathrm{Mg}$, in the matrix from $\mathrm{DH} 4$ at $3 \mathrm{~m}$, M-S-H [9], as well as $\mathrm{Fe}^{2+}$-Si coprecipitates [20]. The data for the solid phase with $\mathrm{Si}$, Fe, and $\mathrm{Mg}$, in the matrix of the clastic sediments from $\mathrm{DH} 4$ at $3 \mathrm{~m}$ had d-spacings similar to $\mathrm{M}-\mathrm{S}-\mathrm{H}$ [9] and $\mathrm{Fe}^{2+}-\mathrm{Si}$ coprecipitates [20], except for the absence of the smaller peaks. Overall, the data here suggest that the solid phase with $\mathrm{Si}, \mathrm{Fe}$, and $\mathrm{Mg}$, in the infillings from the shallower parts could be assigned as amorphous or poorly crystalline components related to M-S-H and F-S-H.

Table 3. Details of d-spacings of the solid phase with $\mathrm{Si}, \mathrm{Fe}$, and $\mathrm{Mg}$, in the matrix of $\mathrm{DH} 4$ at $3 \mathrm{~m}$ determined by TEM, the M-S-H data by XRD [9], and the $\mathrm{Fe}^{2+}-\mathrm{Si}$ coprecipitates data by XRD [20]. All d-spacings are in $\AA$.

\begin{tabular}{ccc}
\hline Minerals at Matrix from DH4 at Depth $\mathbf{3} \mathbf{~}$ & $\mathbf{M}-\mathbf{S}-\mathbf{H}$ & $\mathbf{F e}^{\mathbf{2 +}}$-Si Coprecipitates \\
\hline- & - & $14-15.5$ \\
4.55 & 4.51 & 4.54 \\
- & 3.34 & 3.41 \\
2.59 & 2.56 & 2.61 \\
- & - & 2.28 \\
- & - & 1.70 \\
1.53 & 1.54 & 1.52 \\
\hline
\end{tabular}




\subsection{Formation of $\mathrm{Fe}$-and $\mathrm{Mg}$-Rich Smectite under Hyperalkaline Conditions}

Smectite was found to be present under hyperalkaline conditions, but it is still uncertain whether the smectite at this site was produced by direct precipitation from the hyperalkaline groundwater, by alkaline alteration of minerals in the clastic sediments, or transported from other locations. Smectite was observed as infilled components in the matrix of the clastic sediments together with tobermorite (Figure 6). This could support that smectite was formed under alkaline conditions. However, uncertainty remains because smectite is also known to be produced by the weathering of ultramafic minerals, such as olivine and pyroxene, under non-alkaline conditions [21]. An accurate determination of the origins of the smectite is important; if the smectite was formed under hyperalkaline conditions at this location, then the present study must focus on smectite formation under hyperalkaline conditions. If, however, the smectite was formed elsewhere, and transported and deposited at the site, the focus of the study becomes on smectite stability under hyperalkaline conditions.

Smectite from the deeper parts of the samples here was rich in clastic sediments, and Fe- and Mg-rich smectite was present as infillings in the matrix of the clastic sediments (samples from DH4 at $6 \mathrm{~m}$, Figure 6c). In the shallower samples (samples from DH4 at $3 \mathrm{~m}$, Section 5.3 above), amorphous or poorly crystalline material, such as M-S-H and F-S-H, was present as an infilled component in the matrix of the clastic sediments. Figure 8 is a phase diagram for the Mg-Si-Fe-Al-Na system, where the chemical compositions of the hyperalkaline groundwater is plotted within the stability fields of $\mathrm{Mg}$ - and Fe-rich smectite (Fe saponite). However, the fluids are not plotted at the boundary of Mgand Fe-rich smectite. When these thermodynamically stable phases are suppressed from the diagram, they plot along the solubility line of M-S-H. This suggests that the concentrations of dissolved $\mathrm{Mg}$ and $\mathrm{Si}$ in the hyperalkaline groundwater are controlled by dissolution or precipitation of M-S-H and not by dissolution or precipitation of stable phases, such as smectite. As above, from the EPMA and TEM observations, M-S-H was present in the matrix of the clastic sediments, altogether suggesting that M-S-H was precipitated from the hyperalkaline groundwater.

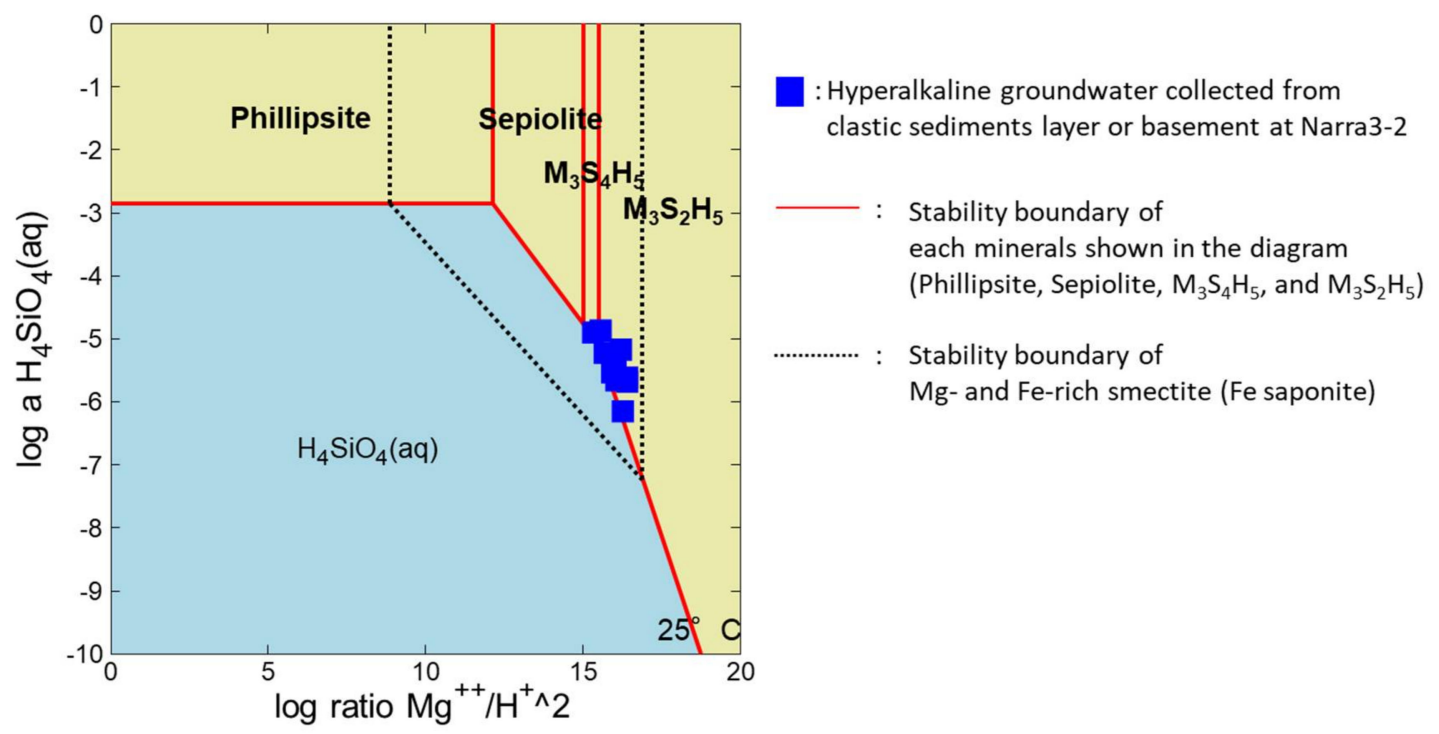

Figure 8. Phase diagram for the Mg-Si-Fe-Al-Na system. Blue squares represent hyperalkaline groundwater collected from the clastic sediment layer or basement at Narra3-2. Dotted lines show stability boundaries of $\mathrm{Mg}$ - and Fe-rich smectite (Fe saponite). $\mathrm{M}_{3} \mathrm{~S}_{4} \mathrm{H}_{5}: \mathrm{M}-\mathrm{S}-\mathrm{H}\left(3 \mathrm{MgO} \cdot 4 \mathrm{SiO}_{2} \cdot 5 \mathrm{H}_{2} \mathrm{O}\right) ; \mathrm{M}_{3} \mathrm{~S}_{2} \mathrm{H}_{5}$ : M-S-H $\left(3 \mathrm{MgO} \cdot 2 \mathrm{SiO}_{2} \cdot 5 \mathrm{H}_{2} \mathrm{O}\right)$.

The smectite in the matrix of the clastic sediments from deeper underground showed a similar occurrence pattern as the amorphous or poorly crystalline components, such as M-S-H, from the shallower parts. A previous study reported that the structure of M-S-H could be similar to 2:1 
phyllosilicates, with vacancies of $\mathrm{Si}$ in the tetrahedral sites [18]. Because of structural and chemical similarities between M-S-H and smectite, this suggests the possibility that M-S-H was precipitated from hyperalkaline groundwater first by the interaction between clastic sediments and hyperalkaline groundwater and then kinetically altered to smectite. Although the relation with the dissolved $\mathrm{Fe}^{2+}$ or $\mathrm{Fe}^{3+}$ concentrations and the formation of F-S-H is not well understood, F-S-H could be precipitated or co-precipitated with M-S-H to form the solid phase with $\mathrm{Si}$, Fe, and $\mathrm{Mg}$, then the solid phase with $\mathrm{Si}$, $\mathrm{Fe}$, and $\mathrm{Mg}$ could alter to the Fe- and Mg-rich smectite.

The chemistry of the hyperalkaline groundwater may be controlled by geochemical reactions of meteoric waters in the Palawan ophiolite. This would suggest that hyperalkaline groundwater is more likely to flow further than required for the deposition of clastic sediments here, and the clastic sediments would have been more likely to interact with the hyperalkaline groundwater, since clastic sediments were deposited at Narra3-2. The ${ }^{14} \mathrm{C}$ dating of woods in the sediments collected from different depths at T5 showed the burial age of the woods from deeper strata to be older than that of woods buried in more shallow strata. This indicates that the clastic sediments at Narra3-2 could have been deposited and accumulated gradually. Therefore, the estimated time-scale of the interaction between sediments and hyperalkaline groundwater would be longer when sediments are present in deeper strata. This suggests that the solid phase with $\mathrm{Si}, \mathrm{Fe}$, and $\mathrm{Mg}$, in the smectite-rich deeper parts would have been exposed to the hyperalkaine groundwater longer than in the smectite-poor shallower parts. The results support a conclusion that the smectite here was produced under hyperalkaline conditions via amorphous or poorly crystalline components such as M-S-H and F-S-H, by the interaction between clastic sediments and hyperalkaline groundwater. Such a formation process for smectite is consistent with the situation where smectite was present in the matrix of the clastic sediments from deeper parts (like in DH4 at $6 \mathrm{~m}$ ) and that amorphous or poorly crystalline components such as M-S-H and F-S-H were present in the matrix of the clastic sediments from the shallower parts (like in DH4 at $3 \mathrm{~m}$ ).

The ${ }^{14} \mathrm{C}$ dating of the woods supports the deposited age of the woods as well as the sediments, and the age also agrees with the interaction time-scale between clastic sediments and hyperalkaline groundwater. This makes it likely that smectite would have been produced under hyperalkaline conditions over a period of thousands of years or longer.

\subsection{Implications of the Study}

There are reports of Fe- or Mg-rich smectite detected in Noachian-aged and early Hesperian-aged terrains on Mars [22,23]. A generally accepted formation pathway of smectite is aqueous alteration of mafic rock in surface or subsurface environments at neutral to alkaline $\mathrm{pH}$ [22,24], although full details of the formation conditions of smectite are still not established and a previous study has suggested the possibility that smectite on Mars was formed under moderately acidic conditions [25]. The formation process of smectite in the area of the present study is an analogue of the generally accepted pathway that may have occurred on early Mars. This indicates that our suggested process of smectite formation under hyperalkaline conditions is not extraordinary and may have occurred here, as well as on early Mars.

There is much reported experimental work on the formation of zeolite after alkaline alteration of bentonite [1-3], as well as work on the natural analogue study of the Zambales ophiolite reporting the formation of smectite after alkaline alteration of bentonite [4]. Because smectite could play an important role as a hydrologic barrier and provide nuclide isolation in repositories, it is important to understand what factors determine the formation of secondary mineral species. Our study proposes that smectite would be produced under hyperalkaline conditions via amorphous or poorly crystalline components, such as M-S-H and/or F-S-H. Previous studies have reported that a certain amount of $\mathrm{Mg}^{2+}$ and/or $\mathrm{Fe}^{2+}$ is necessary for the formation of smectite during synthesis at low temperatures $[26,27]$. From the present and previous studies [26,27], the controlling factor in the formation of smectite or zeolite as secondary minerals after alkaline alteration of bentonite may be whether the nuclei of M-S-H and/or F-S-H will be formed. During experiments with alkaline alteration of bentonite, increases in 
magnesium in a non-exchangeable form have also been reported concurrently with the formation of zeolite [28]. This would have been due to the formation of M-S-H, and is consistent with the results of the present study. These previous findings suggest that $\mathrm{Fe}^{2+}$ should be examined carefully together with $\mathrm{Mg}^{2+}$ when considering the interaction between bentonite and hyperalkaline fluids in future work.

Previous natural analogue research from Cyprus reported the naturally-occurring formation of Fe-bearing palygorskite as a result of bentonite alteration by alkaline fluids [10]. Because the constituent elements of Fe-bearing palygorskite include $\mathrm{Mg}$ and $\mathrm{Fe}$, a certain amount of $\mathrm{Mg}^{2+}$ and $\mathrm{Fe}^{2+}$ would be expected in this system. Factors that differentiate smectite and palygorskite as secondary minerals after alkaline alteration of bentonite are still unknown. A previous study that conducted a mineralogical investigation at the Troodos Ophiolite Complex in Cyprus observed emplacement of Aland Fe-rich smectite by palygorskite [29]. The study attributed the emplacement to the high-Si activity of pore waters, implying that the Si-activity of pore water is a factor that should be examined carefully, together with the effect of Al.

\section{Conclusions}

In the present paper, Fe- and Mg-rich smectite in clastic sediments interacting with hyperalkaline groundwater was found at Narra in Palawan, Philippines. The hyperalkaline groundwater present was likely a result of geochemical reactions of meteoric water with the Palawan ophiolite. Fe- and Mg-rich smectite, as well as amorphous or poorly crystalline components such as M-S-H and F-S-H, were present as infilled components in the matrix of the clastic sediments. From the chemistry of the hyperalkaline groundwater and the occurrences of the amorphous or poorly crystalline components such as M-S-H and F-S-H, M-S-H may have been precipitated from the hyperalkaline groundwater, and F-S-H may have been precipitated or co-precipitated with M-S-H. The presence of authigenic tobermorite as an infilling compound supports the suggestion that the major infilled components in the matrix of the clastic sediments was formed by an interaction between the clastic sediments and hyperalkaline groundwater. Therefore, a certain amount of smectite could have been generated under hyperalkaline conditions, by alteration from amorphous or poorly crystalline components, such as M-S-H and F-S-H.

The formation process of smectite under alkaline conditions suggested by the results here is analogous to the generally accepted model of smectite formation that may have taken place on early Mars. This indicates that the formation process suggested here is not an extraordinary but a highly possible process.

In repositories for radioactive waste, alkaline alteration of bentonite is a concern, and it would seem crucial for safety assessments to verify whether smectite will be formed as a secondary mineral after alkaline alteration of bentonite. This is because smectite could play an important role in hydrologic barriers and act to isolate nuclides in repositories. The study here provides new details of secondary mineral formation after bentonite dissolution under hyperalkaline conditions in repositories. Therefore, the factor that could control whether smectite or zeolite are formed as secondary minerals after alkaline alteration of bentonite is whether nuclei of M-S-H and/or F-S-H are formed or not. This could be determined by the presence of dissolved $\mathrm{Mg}^{2+}$ and $\mathrm{Fe}^{2+}$ in the environment. These findings suggest that the presence of $\mathrm{Fe}^{2+}$ should be examined carefully together with $\mathrm{Mg}^{2+}$ when considering the interaction between bentonite and hyperalkaline fluids in future work.

Acknowledgments: This research was initiated under a project of "natural analogue studies" to develop geological disposal technologies in Japan and was funded by the Ministry of Economy Trade and Industry (METI), Japan. The research was supported by a Joint Research Grant for a "Nanotechnology Platform" Program of the Ministry of Education, Culture, Sports, Science and Technology (MEXT), Japan. The authors wish to thank Yukinobu Kimura of the Obayashi Corporation for the fluid analyses, W. Russell Alexander of Bedrock Geosciences and Carlo Arcilla at the University of the Philippines for valuable advice throughout the research and in setting up the field survey, and Hisao Satoh of Mitsubishi Materials Corporation for the EPMA analyses. The authors also thank Masanobu Nishimura of Obayashi Corporation and Tatsuaki Nakazuka of Kiso-Jiban Consultants Corporation 
for the field survey. Analyses of ${ }^{14} \mathrm{C}$ dating were performed under the Shared Use Program of JAEA Facilities [JAEA-AMS-TONO].

Author Contributions: M.S. was the principal author and conducted the field survey, sampling, analyses, experiments, and writing of this paper. T.S. was the chief supervisor of M.S. in the master's course. T.S. designed the study. T.O. was also a supervisor, conducted the field survey and provided geochemical advice. N.F. was the principal overseer of the project. M.Y. contributed to the study as a geologist and petrologist.

Conflicts of Interest: The authors declare no conflict of interest.

\section{References}

1. Fernàndez, R.; Cuevas, J.; Sànchez, L.; Vigil de la Villa, R.; Santiago, L. Reactivity of the cement-Bentonite interface with alkaline solutions using transport cells. Appl. Geochem. 2006, 21, 977-992. [CrossRef]

2. Vigil de la Villa, R.; Cuevas, J.; Ramîrez, S.; Leguey, S. Zeolite formation during the alkaline reaction of bentonite. Eur. J. Mineral. 2001, 635-644. [CrossRef]

3. Ruiz, R.; Blanc, C.; Pesquera, C.; Gonzilez, F.; Lpez, J.L.; Benito, I. Zeolitization of a bentonite and its application to the removal of ammonium ion from waste water. Appl. Clay Sci. 1997, 12, 73-83. [CrossRef]

4. Fujii, N.; Yamakawa, M.; Shikazono, N.; Sato, T. Geochemical and Mineralogical Characterizations of Bentonite interacted with Alkaline Fluids generating in Zambales Ophiolite, Northwestern Luzons, Philippines. Geol. Soc. Jpn. 2014, 120, 361-375. [CrossRef]

5. Mitchell, A.H.G.; Hernandez, F.; Dela Cruz, A.P. Cenozoic evolution of the Philippine Archipelago. J. Southeast Asian Earth Sci. 1986, 1, 3-22. [CrossRef]

6. Aurelio, M.A.; Forbes, M.T.; Joy, K.; Taguibao, L.; Savella, R.B.; Bacud, J.A.; Franke, D.; Pubellier, M.; Savva, D.; Meresse, F.; et al. Middle to Late Cenozoic tectonic events in south and central Palawan (Philippines) and their implications to the evolution of the south-eastern margin of South China Sea: Evidence from onshore structural and offshore seismic data. Mar. Pet. Geol. 2014, 58, 658-673. [CrossRef]

7. Shirozu, H. Introduction to Clay Mineralogy_Fundamentals for Clay Science; Asakura Bookseller: Tokyo, Japan, 1988.

8. Christidis, G.E.; Mitsis, I. A new Ni-rich stevensite from the ophiolite complex of Othrys, Central Greece. Clays Clay Miner. 2006, 54, 653-666. [CrossRef]

9. Nied, D.; Enemark-rasmussen, K.; Hopital, E.L.; Skibsted, J.; Lothenbach, B. Properties of magnesium silicate hydrates (M-S-H). Cem. Concr. Res. 2016, 79, 323-332. [CrossRef]

10. Milodowski, A.E.; Norris, S.; Alexander, W.R. Minimal alteration of montmorillonite following long-term interaction with natural alkaline groundwater: Implications for geological disposal of radioactive waste. Appl. Geochem. 2016, 66, 184-197. [CrossRef]

11. Anraku, S.; Matsubara, I.; Morimoto, K.; Sato, T. Geochemical Factors for Secondary Mineral Formation at Naturally-Occurring Hyperalkaline Spring in Oman Ophiolite. J. Clay Sci. Soc. Jpn. 2017, 55, 17-30. [CrossRef]

12. Barnes, I.; Neil, J.R.O. The Relationship between Fluids in Some Fresh Alpine-Type Ultramafics and Possible Modern Serpentinization, Western United States. Geol. Soc. Am. Bull. 1969, 80, 1947-1960. [CrossRef]

13. Bruni, J.; Canepa, M.; Chiodini, G.; Cioni, R.; Cipolli, F.; Longinelli, A.; Marini, L.; Ottonello, G.; Vetuschi, M. Irreversible water-Rock mass transfer accompanying the generation of the neutral, $\mathrm{Mg}-\mathrm{HCO}_{3}$ and high-pH, $\mathrm{Ca}-\mathrm{OH}$ spring waters of the Genova province, Italy. Appl. Geochem. 2002, 17, 455-474. [CrossRef]

14. Suzuki, S.; Sinn, E. $1.4 \mathrm{~nm}$ tobermorite-like calcium silicate hydrate prepared at room temperature from $\mathrm{Si}(\mathrm{OH})_{4}$ and $\mathrm{CaCl}_{2}$ solutions. J. Mater. Sci. Lett. 1993, 12, 542-544.

15. Hong, S.; Glasser, F.P. Alkali binding in cement pastes Part I. The C-S-H phase. Cem. Concr. Res. 2000, 29, 1893-1903. [CrossRef]

16. Decarreau, A.; Colin, F.; Herbillon, A.; Manceau, A.; Nahon, D.; Paquet, H.; Trauth-badaud, D.; Trescases, J.J. DOMAIN SEGREGATION IN Ni-Fe-Mg-SMECTITES. Clays Clay Miner. 1987, 35, 1-10. [CrossRef]

17. Gainey, S.R.; Hausrath, E.M.; Adcock, C.T.; Ehlmann, B.L.; Xiao, Y.; Bartlett, C.L.; Tschauner, O.; Hurowitz, J.A. Clay mineral formation under oxidized conditions and implications for paleoenvironments and organic preservation on Mars. Nat. Commun. 2017, 1-7. [CrossRef] [PubMed] 
18. Roosz, C.; Grangeon, S.; Blanc, P.; Montouillout, V.; Lothenbach, B.; Henocq, P.; Giffaut, E.; Vieillard, P.; Gaboreau, S. Crystal structure of magnesium silicate hydrates (M-S-H): The relation with 2:1 Mg-Si phyllosilicates. Cem. Concr. Res. 2015, 73, 228-237. [CrossRef]

19. Zhang, T.; Vandeperre, L.J.; Cheeseman, C.R. Formation of magnesium silicate hydrate (M-S-H) cement pastes using sodium hexametaphosphate. Cem. Concr. Res. 2014, 65, 8-14. [CrossRef]

20. Decarreau, A.; Bonnin, D. Synthesis and Crystallogenesis at Low Temperature of Fe (III)-Smectites by Evolution of Coprecipitated Gels: Experiments in Partially Reducing Conditions. Clay Miner. 1986, 21, 861-877. [CrossRef]

21. Banfield, J.F.; Jones, B.F.; Veblen, D.R. An AEM-TEM study of weathering and diagenesis, Albert Lake, Oregon. I. Weathering reactions in the volcanics. Geochim. Cosmochim. Acta 1991, 55, 2781-2793. [CrossRef]

22. Bishop, J.L.; Loizeau, D.; Mckeown, N.K.; Saper, L.; Dyar, M.D.; Des, D.J.; Parente, M.; Murchie, S.L. What the ancient phyllosilicates at Mawrth Vallis can tell us about possible habitability on early Mars. Planet. Space Sci. 2013, 86, 130-149. [CrossRef]

23. Vaniman, D.T.; Bish, D.L.; Ming, D.W.; Bristow, T.F.; Morris, R.V.; Blake, D.F.; Chipera, S.J.; Morrison, S.M.; Treiman, A.H.; Rampe, E.B.; et al. Mineralogy of a Mudstone at Yellowknife Bay, Gale Crater, Mars. Sciences 2013, 1-15. [CrossRef] [PubMed]

24. Chemtob, S.M.; Nickerson, R.D.; Morris, R.V.; Agresti, D.G.; Catalano, J.G. Synthesis and structural characterization of Ferrous trioctahedral smectites: Implications for clay mineral genesis and detectability on Mars. J. Geophys. Res. Planets 2015, 120, 1119-1140. [CrossRef]

25. Peretyazhko, T.S.; Sutter, B.; Morris, R.V.; Agresti, D.G.; Le, L.; Ming, D.W. Fe/Mg smectite formation under acidic conditions on early Mars. Geochim. Cosmochim. Acta 2016, 173, 37-49. [CrossRef]

26. Harder, H. The Role of Magnesium in the Formation of Smectite Minerals. Chem. Geol. 1971, 10, 31-39. [CrossRef]

27. Harder, H. Nontronite Synthesis at Low Temperatures. Chem. Geol. 1976, 18, 169-180. [CrossRef]

28. Ramírez, S.; Cuevas, J.; Vigil, R.; Leguey, S. Hydrothermal alteration of "La Serrata" bentonite (Almeria, Spain) by alkaline solutions. Appl. Clay Sci. 2002, 21, 257-269. [CrossRef]

29. Christidis, G.E. Genesis and compositional heterogeneity of smectites. Part III: Alteration of basic pyroclastic rocks-A case study from the Troodos Ophiolite Complex, Cyprus. Am. Mineral. 2006, 91, 685-701. [CrossRef] 